\title{
Genetic epidemiology of single gene defects in Chile
}

\author{
Ricardo Cruz-Coke, Rodrigo S Moreno
}

\begin{abstract}
We have studied the correlation between the ethnic structure and the prevalence of single gene defects in Chile. At present the Chilean population is approximately $64 \%$ white and $35 \%$ Amerindian with traces of other admixture. Fewer than $4 \%$ of the Chilean population are foreign born. Investigations indicate that all severe diseases and many others without impaired reproduction have mutation rates within the range of the white population. Classical ethnic diseases are very rare. Autosomal recessive disorders have a wide range of variability: cystic fibrosis has a low incidence and PKU has a similar incidence to English rates. Only $30 \%$ of the inborn errors of metabolism have been described in Chilean medical publications. In addition, no Chilean haemoglobin or haptoglobin variants have been described.

Some rare inherited diseases in Chilean human isolates have been described, including achromatopsia, chondrocalcinosis, and Creutzfeldt-Jakob disease. The prevalence of intrahepatic cholestasis of pregnancy and supernumerary nipples is the highest in the world and they are associated with aboriginal origin. Single gene defects in Chile are probably shaped by factors related to its ethnic population structure. These local rare single gene defects may be good markers of population admixture for genetic epidemiological studies.
\end{abstract}

( $($ Med Genet 1994;31:702-706)

Medical Genetics Unit, Hospital Clinico "J J Aguirre", Universidad de Chile, Santos Dumont 999, Santiago, Chile R Cruz-Coke

Medical Genetics Unit, Hospital Exequiel Gonzaléz Cortés, Santiago, Chile, and Cellular Biology and Genetics Department, Facultad Medicina Universidad de Chile, Casilla 70061, Correo 7, Santiago, Chile RS Moreno

Correspondence to Dr Cruz-Coke.

Received 19 January 1994 Revised version accepted for Revised version accepted for
publication 30 March 1994
The population frequency of single gene defects depends mainly on their mode of inheritance, mutation rate, and reproductive fitness. Other factors are defined by population features such as migration, inbreeding, assortative mating, and population size.

The population gene frequency of dominant and $\mathrm{X}$ linked disorders depends on impaired reproduction. With impaired reproduction, the incidence and prevalence are mainly determined by the mutation rate. The sources of selection against these mutations are disease specific and are presumably similar in all populations. Without impaired reproduction, the incidence may be unequal in different populations depending on factors such as population size, demographic history, breeding structure, and ethnic origin. However, in autosomic recessive disorders, the various influences that have shaped the current frequencies are largely unknown, as is their incidence. Epidemiological surveys show that these diseases have a variable incidence in the ethnic population.

The ethnic sources of Chilean populations are basically an admixture between Amerindian and European peoples. Five centuries ago the Spanish conquest and the infectious diseases they introduced decimated the Amerindian population. Consequently, the Spanish population increased and the percentage of European admixture, which was initially small, increased. The Chilean population is grossly two-thirds white and one-third Amerindian admixture. During the last century immigrants never exceeded $4 \%$ of the population. ${ }^{2}$ Black and Asiatic admixture is extremely low. Therefore, these differences must be seen in the diseases associated with ethnic groups rates.

The most common polymorphic genes have been surveyed in the Chilean population and different genetic diseases have been described, but their epidemiological characteristics are largely unknown in relationship to their population structure.

The purpose of this paper is to report the rates of single gene disease in Chile and to compare them with international data to review the influence of ethnic factors on the prevalence of single gene defects in Chile.

\section{Materials and methods}

The prevalence of single gene defects included in Mendelian inheritance in $\mathrm{man}^{3}$ was grossly estimated for Chile. This was done by reviewing Chilean data obtained from published medical reports and hospital discharge records, estimating the rates in the twelve million population of Chile.

The results are shown in the tables and a circular diagram of the human genome. In this diagram (figure), prevalence is shown in a logarithmic scale, the frequency being one per million on the perimeter of the circle and one to one in the centre. This central point represents the fixation point of a single mutant gene. International prevalence rates are included for comparison. ${ }^{45}$

In the Amerindian populations of Chile before the arrival of the Spaniards, the $O$ alleles of the ABO blood group and positive Rhesus factor of the $R h$ system had fixed frequencies. Thus, the genetic admixture of the Chilean population, estimated by European admixture with alleles $\mathrm{A}, \mathrm{B}$, and $\mathrm{Rh}$ negative factor, in different Chilean population groups is shown in tables 1 and 2 by their ethnic structure. ${ }^{6-9}$ 


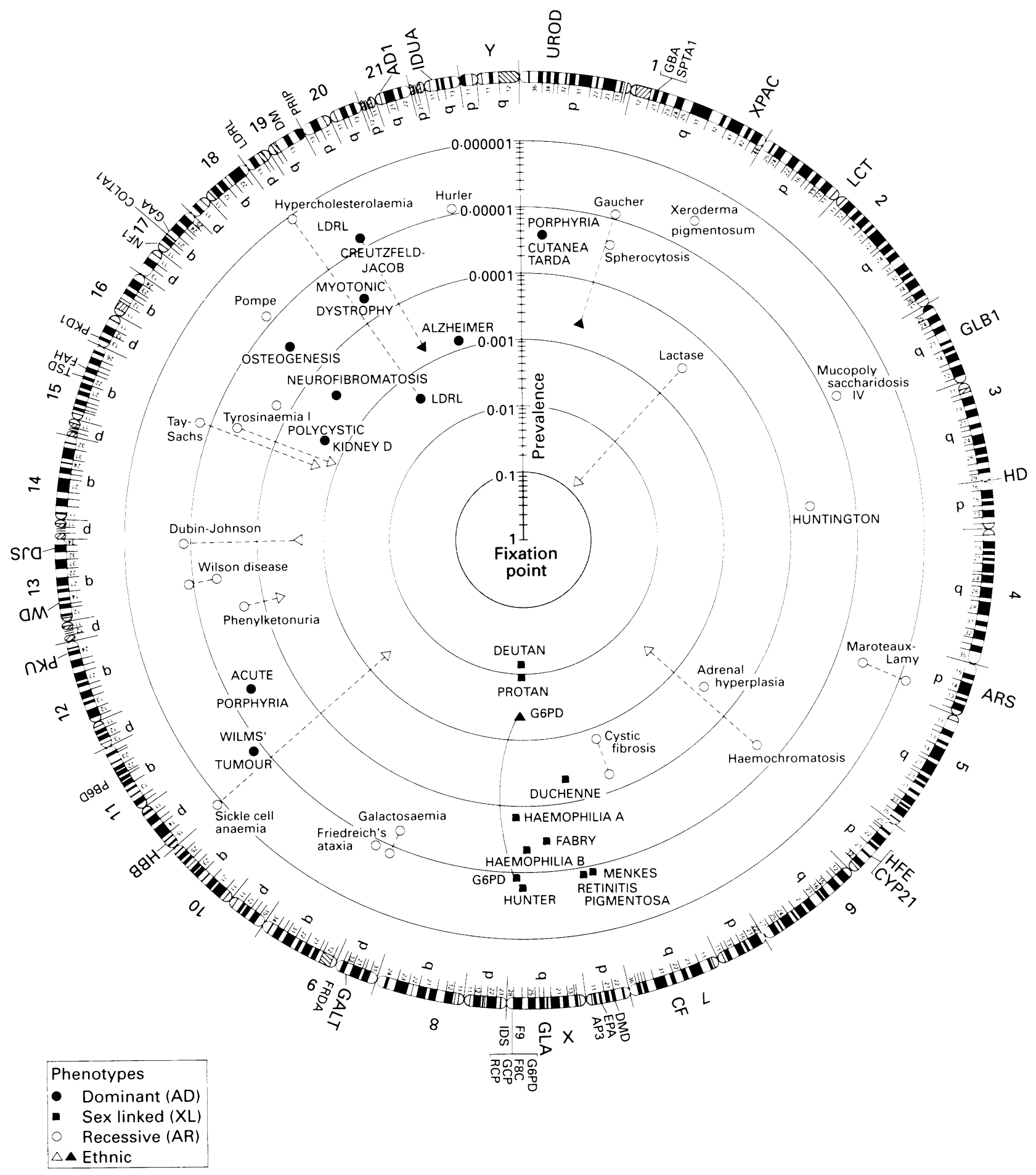

The precalence of single gene defects in the human genome. Prealence is shown on a logarithmic siale, the frequency being one per million on the perimeter and one to one in the centre (fixation point). Different figures linked by dashied line indicate different zalues for general, ethnic, or Chilean populations. 
Table 1 European admixture in the Chilean population

\begin{tabular}{lrll}
\hline Type of population & No & $\begin{array}{l}\text { European } \\
\text { admixture (\%) }\end{array}$ & Reference \\
\hline Indian isolates & & & \\
$\quad$ Aymara & 26 & 4 & 6 \\
$\quad$ Pehuenche & 148 & 5 & 6 \\
Alacaluf & 44 & 9 & 6 \\
Atacameo & 80 & 12 & 6 \\
$\quad$ Mapuche & 450 & 23 & 6 \\
Urban blood banks & & & \\
$\quad$ Santiago North & 63309 & 61 & 7 \\
$\quad$ Valparaiso & 1000 & 77 & 6 \\
$\quad$ Concepcion & 9252 & 75 & 9 \\
$\quad$ Santiago East & 11668 & 81 & \\
\hline
\end{tabular}

Table 2 European admixture in the Chilean population by socioeconomic level in urban centres

\begin{tabular}{lll}
\hline & \multicolumn{2}{l}{ European admixture } \\
\cline { 2 - 3 } Socioeconomic level & $\begin{array}{l}\text { Santiago } \\
(\%)\end{array}$ & $\begin{array}{l}\text { Valparaiso } \\
(\%)\end{array}$ \\
\hline High & 91 & 73 \\
Middle & 70 & 68 \\
Low & 41 & 48 \\
\hline
\end{tabular}

Results

Table 1 shows that the percentage of European admixture is low in Amerindian isolates (mean $10.6 \%)$ and high in the general Chilean population (mean $73.5 \%$ ). In addition, this admixture showed a wide range of variation with socioeconomic levels in urban centres (table 2). ${ }^{68}$

The circle in the figure is a summary of the prevalence of current single gene defects diagnosed in Chile. This figure is based on data from tables $3 \mathrm{~A}, \mathrm{~B}, \mathrm{C}$, and included our review and estimations for Chile compared with international prevalences. ${ }^{45}$

Some classical ethnic disease rates found in international publications are compared with published cases diagnosed in Chile in table $4 .^{510}$

Table 5 includes some rare inherited diseases discovered in Chilean isolates. They are achromatopsia, ${ }^{11}$ chondrocalcinosis, ${ }^{12}$ and Creutz-

Table 3A Prevalence of single gene defects: autosomal dominant

\begin{tabular}{|c|c|c|c|c|c|c|}
\hline \multirow[b]{2}{*}{ Locus } & \multirow[b]{2}{*}{ Symbol } & \multirow[b]{2}{*}{ Single gene defects } & \multirow[b]{2}{*}{$M I M$} & \multicolumn{2}{|c|}{ Estimated prevalence } & \multirow[b]{2}{*}{ Chile } \\
\hline & & & & General & Ethnic & \\
\hline $1 \mathrm{p} 34$ & UROD & Porphyria cutanea tarda & 176100 & $1 / 50000$ & & $1 / 50000$ \\
\hline lq 21 & SPTA1 & Spherocytosis, recessive & 182860 & & $1 / 5000$ & $1 / 50000$ \\
\hline $2 \mathrm{p} 25$ & AN1 & Aniridia-1 & 106200 & $<1 / 100000$ & & Very rare \\
\hline $4 \mathrm{p} 16.3$ & $\mathrm{HD}$ & Huntington's disease & 143100 & $1 / 25000$ & & $1 / 25000$ \\
\hline $11 \mathrm{p} 15.5$ & $\mathrm{HBB}$ & Sickle cell anaemia & 141900 & $<1 / 1000000$ & $1 / 625$ & $<1 / 1000000$ \\
\hline $11 \mathrm{p} 15.5$ & WT2 & Wilms' tumour, type 2 & 194071 & $<1 / 100000$ & & $<1 / 100000$ \\
\hline $11 \mathrm{q} 23$-qter & PBGD & Porphyria, acute intermittent & 176000 & $1 / 66000$ & & $1 / 100000$ \\
\hline $16 \mathrm{p} 13.31-\mathrm{p} 13.12$ & PKDl & Polycystic kidney disease & 173900 & $1 / 2500$ & & $1 / 2280$ \\
\hline $17 \mathrm{q} 11.2$ & NF1 & Neurofibromatosis & 162200 & $1 / 5000$ & & Common \\
\hline $17 \mathrm{q} 21.31-\mathrm{q} 22.05$ & COL1A1 & Osteogenesis imperfecta & 120150 & $1 / 50000$ & & $1 / 100000$ \\
\hline $19 \mathrm{p} 13.2-\mathrm{pl} 3.1$ & LDLR & Hypercholesterolaemia, familial & 143890 & $1 / 1000000$ & $1 / 500$ & $1 / 1000000$ \\
\hline $19 \mathrm{q} 13$ & $\mathrm{DM}$ & Myotonic dystrophy & 160900 & $1 / 25000$ & & $1 / 75000$ \\
\hline 20 pter-p12 & PRIP & Creutzfeldt-Jakob disease & 123400 & $<1 / 100000$ & & $1 / 100000$ \\
\hline $21 \mathrm{q} 11.2-\mathrm{q} 21$ & $\mathrm{ADl}$ & Alzheimer's disease & 104300 & $1 / 1000$ & & $1 / 1000$ \\
\hline
\end{tabular}

Table 3B Prevalence of single gene defects: autosomal recessive

\begin{tabular}{|c|c|c|c|c|c|c|}
\hline \multirow[b]{2}{*}{ Locus } & \multirow[b]{2}{*}{ Symbol } & \multirow[b]{2}{*}{ Single gene defects } & \multirow[b]{2}{*}{$M I M$} & \multicolumn{2}{|c|}{ Estimated prevalence } & \multirow[b]{2}{*}{ Chile } \\
\hline & & & & General & Ethnic & \\
\hline $1 \mathrm{q} 21$ & GBA & Gaucher disease & 230800 & $1 / 100000$ & $1 / 2000$ & $<1 / 100000$ \\
\hline 1q42-qter & XPAC & ?Xeroderma pigmentosum & 278700 & $1 / 250000$ & & Very rare \\
\hline 2 & LCT & ?Lactase deficiency, congenital & 223000 & & $1 / 10$ & $1 / 5000$ \\
\hline $3 \mathrm{p} 21-\mathrm{p} 14.2$ & GLB1 & Mucopolysaccharidosis IVB & 230500 & $<1 / 100000$ & & Very rare \\
\hline 5 p11-q13 & ARSB & Maroteaux-Lamy syndrome & 253200 & $<1 / 1000000$ & & None \\
\hline $6 \mathrm{p} 21.3$ & CYP21 & Adrenal hyperplasia, congenital & 201910 & $1 / 8000$ & & $1 / 15000$ \\
\hline $6 \mathrm{p} 21.3$ & $\mathrm{HFE}$ & Haemochromatosis & 235200 & & $1 / 400$ & $1 / 50000$ \\
\hline $6 \mathrm{p} 21.3$ & IDDM & $\begin{array}{l}\text { Diabetes mellitus, insulin } \\
\text { dependent }\end{array}$ & 222100 & $1 / 600$ & & $1 / 1000$ \\
\hline $7 q 31.3-q 32$ & $\mathrm{CF}$ & Cystic fibrosis & 219700 & $1 / 2000$ & & $1 / 3500$ \\
\hline $9 \mathrm{p} 13$ & GALT & Galactosaemia & 230400 & $1 / 62000$ & & $1 / 40000$ \\
\hline $9 \mathrm{q} 13-\mathrm{q} 21.1$ & FRDA & Friedreich's ataxia & 229300 & $<1 / 100000$ & & Very rare \\
\hline $12 \mathrm{q} 24.1$ & PKU1 & Phenylketonuria & 261600 & $1 / 10000$ & & $1 / 14625$ \\
\hline $13 \mathrm{q} 14-\mathrm{q} 21$ & WD & Wilson disease & 277900 & $1 / 50000$ & & $<1 / 100000$ \\
\hline $13 \mathrm{q} 34$ & DJS & ?Dubin-Johnson syndrome & 237500 & & $1 / 3000$ & $<1 / 100000$ \\
\hline $15 \mathrm{q} 22-225.1$ & TSD & Tay-Sachs disease: GM2 & 272800 & & $1 / 3000$ & $<1 / 100000$ \\
\hline $15 \mathrm{q} 23-\mathrm{q} 25$ & FAH & Tyrosinaemia, type I & 276700 & $1 / 100000$ & & $1 / 150000$ \\
\hline 17 & NPD & Niemann-Pick disease & 257200 & & $1 / 10000$ & Very rare \\
\hline $17 \mathrm{q} 23$ & GAA & Pompe disease & 232300 & $1 / 100000$ & & $1 / 150000$ \\
\hline $22 \mathrm{q} 11$ & IDUA & Mucopolysaccharidosis I & 252800 & $1 / 100000$ & & Rare \\
\hline
\end{tabular}

Table 3C Prevalence of single gene defects: sex linked

\begin{tabular}{|c|c|c|c|c|c|c|}
\hline \multirow[b]{2}{*}{ Locus } & \multirow[b]{2}{*}{ Symbol } & \multirow[b]{2}{*}{ Single gene defects } & \multirow[b]{2}{*}{$M I M$} & \multicolumn{2}{|c|}{ Estimated prevalence } & \multirow[b]{2}{*}{ Chile } \\
\hline & & & & General & Ethnic & \\
\hline Xpter-p22.32 & CPXR & Chondrodysplasia punctata & 302950 & $<1 / 1000000$ & & Very rare \\
\hline $\mathrm{Xp} 22.2-\mathrm{p} 22.1$ & CLS & Coffin-Lowry syndrome & 303600 & $<1 / 1000000$ & & Very rare \\
\hline $\mathrm{Xp} 22$ & HYP & Hypophosphataemia, X linked & 307800 & $<1 / 100000$ & & Very rare \\
\hline $\mathrm{Xp} 21.2$ & DMD & Duchenne muscular dystrophy & 310200 & $1 / 3300$ & & $1 / 5000$ \\
\hline $\mathrm{Xp} 21$ & RP3 & Retinitis pigmentosa- 3 & 312610 & $1 / 2000-1 / 7000$ & & Rare \\
\hline $\mathrm{Xq} 12-\mathrm{q} 13$ & MNK & Menkes disease & 309400 & $<1 / 1000000$ & $1 / 34500$ & Very rare \\
\hline $\mathrm{Xq} 22$ & GLA & Fabry disease & 301500 & $1 / 40000$ & & Very rare \\
\hline $\mathrm{Xq} 22-\mathrm{q} 24$ & ATS & Alport syndrome & 301050 & $<1 / 1000000$ & & Very rare \\
\hline $\mathrm{Xq} 26-\mathrm{q} 27.2$ & HPRT & Lesch-Nyhan syndrome & 308000 & $1 / 100000$ & $1 / 10000$ & Very rare \\
\hline $\mathrm{Xq} 27.1-\mathrm{q} 27.2$ & F9 & Haemophilia B & 306900 & $1 / 50000$ & & $1 / 50000$ \\
\hline $\mathrm{Xq} 27.3$ & IDS & Hunter syndrome & 309900 & $1 / 100000$ & & $<1 / 150000$ \\
\hline $\mathrm{Xq} 28$ & GCP & Deutan colour blindness & 303800 & $1 / 70$ & & $1 / 100$ \\
\hline $\mathrm{Xq} 28$ & G6PD1 & Glucose-6-phosphate deficiency & 305900 & $<1 / 1000000$ & $1 / 10$ & $<1 / 100000$ \\
\hline $\mathrm{Xq} 28$ & F8C & Haemophilia A & 306700 & $1 / 10000$ & & $1 / 11000$ \\
\hline $\mathrm{Xq} 28$ & RCP & Protan colour blindness & 303900 & $1 / 100$ & & $1 / 150$ \\
\hline
\end{tabular}


Table 4 Classical ethnic diseases in Chile

\begin{tabular}{lllll}
\hline MIM & Disease & $\begin{array}{l}\text { Ethnic } \\
\text { population }\end{array}$ & $\begin{array}{l}\text { Ethnic } \\
\text { prevalence }\end{array}$ & $\begin{array}{l}\text { No of cases } \\
\text { in Chile }^{10}\end{array}$ \\
\hline 305900 & G6P deficiency & Black, USA & $1 / 50$ & 10 \\
273500 & Thalassaemia & Black, USA & $1 / 100$ & 12 \\
141900 & Sickle cell anaemia & Black, USA & $1 / 625$ & 2 \\
230800 & Gaucher disease & Jews, Israel & $1 / 2000$ & 8 \\
249100 & Mediterranean fever & Jews, Africa & $1 / 2700$ & 1 \\
237500 & Dubin-Johnson disease & Jews, Iran & $1 / 3000$ & 1 \\
272800 & Tay-Sachs disease & Jews, USA & $1 / 3000$ & 12 \\
257200 & Niemann-Pick disease & Jews, USA & $1 / 10000$ & 1 \\
\hline
\end{tabular}

Table 5 Rare single gene defects in human isolates in Chile

\begin{tabular}{lllll}
\hline$M I M$ & Disease & $\begin{array}{l}\text { Geographical } \\
\text { region }\end{array}$ & $\begin{array}{l}\text { No of cases } \\
\text { in Chile }\end{array}$ & Reference \\
\hline 216900 & Achromatopsia & Cachapoal & 10 & 11 \\
118600 & Chondrocalcinosis & Chiloe & 28 & 12 \\
123400 & Creutzfeldt-Jakob disease & Central Chile & 69 & 13 \\
\hline
\end{tabular}

Table 6 Rare single gene defects in Chile: distribution and prevalence by ethnic group

\begin{tabular}{lrll}
\hline Ethnic group & $\begin{array}{l}\text { Supermumerary } \\
\text { nipple (\%o) }\end{array}$ & $\begin{array}{l}\text { Cholestasis } \\
\text { of pregnancy (\%) }\end{array}$ & $\begin{array}{l}\text { Mydriatic } \\
\text { response (\%) }\end{array}$ \\
\hline Chilean & $0.07(18)$ & $2.5(14)$ & $5.8(15)$ \\
Aymara & $113.00(16)$ & $0.0(14)$ & $8.8(15)$ \\
Atacameno & $126.00(16)$ & $\overline{5}$ & - \\
Araucanian & $168.00(17)$ & $5.5(14)$ & - \\
\hline
\end{tabular}

feldt-Jakob disease. ${ }^{13}$ Other single gene defects, such as intrahepatic cholestasis of pregnancy, ${ }^{14}$ mydriatic response, ${ }^{15}$ and supernumerary nipples, ${ }^{16-18}$ found in Amerindian people are shown with their prevalence rates in different populations (table 6).

\section{Discussion}

Epidemiological research in Chile is facilitated because vital statistics of the public and private hospitals and health services are centralised in the National Health Services System (SSNS) of the Ministry of Health and the National Statistics Institute (INE). Birth and death certificates are complete for $91 \%$ of the general population. ${ }^{19}$ Rare diseases are studied in national centres of reference. National centres and clinical genetics units distributed in five major cities communicate their findings to the medical community. All the ethnic population isolates have been surveyed. Consequently the majority of rare hereditary disorders are ascertained in the whole country.

In addition, more than $90 \%$ of births and deaths receive medical attention. Only about $25 \%$ of the discharges are from private hospitals, and are also reported and controlled by the SSNS and INE. ${ }^{1920}$ Also, rare diseases are quickly reviewed at medical meetings and published. The ethnic population groups are not excluded from this health system. ${ }^{19}$ Therefore, information on diseases and completeness of ascertainment are similar in all regions of Chile.

The white admixture in Chile is related to the ethnic structure of its people and the differences between the northern and eastern areas of Santiago city are explained by a socioeconomic cline associated with assortative mating. ${ }^{21}$ This sociogenetic cline is also present in other cities in Chile.

Data on around 50 single gene defects confirm that Chilean prevalence rates of dominant and sex linked disorders with impaired re- production are similar to those published for foreign white populations. ${ }^{22-25}$ The prevalence of those diseases with no impaired reproduction also show values very similar to international ones. ${ }^{26}$ Mutation rates for Huntington's disease calculated in the Chilean population are also comparable to those published elsewhere. ${ }^{23}$

Autosomal recessive disorders showed lower percentages than classical figures for white populations and have a wide range of variation. Only $30 \%$ of the inborn errors of metabolism have been diagnosed in the Chilean population. ${ }^{10}$ In addition, no local haemoglobin or haptoglobin variants have been described in the general Chilean population or in the population of Amerindian origin. ${ }^{1027}$

The rates of classical ethnic diseases in Chile have probably been shaped mainly by the low immigration rate indicated by census data. ${ }^{2}$

There is a high prevalence in Chilean populations of rare inherited diseases such as chondrocalcinosis, Creutzfeldt-Jakob disease, and achromatopsia. ${ }^{11-13}$ These high frequencies are explained by inbreeding and drift in small isolated populations. Also single gene defects in the Amerindian people, such as intrahepatic cholestasis of pregnancy, ${ }^{14}$ mydriatic response, ${ }^{15}$ and supernumerary nipples, ${ }^{1617}$ have the highest prevalence in the world. These diseases show that a correlation exists between prevalence rates and percentage of white admixture. It is suggested that rare local single gene defects may be good markers to use for genetic epidemiological studies in mixed populations.

The authors wish to thank Dr Marta Colombo, Instituto de Nutricion y de Tecnologia en Alimentos, Universidad de Chile, and Dr Jenny Holmgren, Instituto de Rehabilitacion Infantil, Sociedad Pro-Ayuda del Niño Lisiado. Also we thank our Sociedad Pro-Ayuda del Nino Lisiado. Also we thank our coworkers, Drs Ronald Youlton, Silvia Castillo, Patricia Sanz, and Carmen Astete for their collaboration in this work. This
investigation was partially supported by the FONDECYT 1152investigation was partially
90 and 1930884 grants.

1 McKusick VA. The ethnic distribution of disease in the United States. F Chron Dis 1967;20:115-18.

2 Cruz-Coke R. Origen y evolucion etnica de la poblacion chilena. Rev Med Chile 1976;104:365-9.

3 McKusick VA. Mendelian inheritance in man. Catalog of autosomal dominant, autosomal recessive, and X-linked phenoautosomal dominant, autosomal recessive, and X-linked pheno-

types. Baltimore: Johns Hopkins Center for Birth Defects Information Services, 1990

5 Stanbury JB, Wyngaarden JB, Fredrickson DS, Goldstein JL, Brown MS. The metabolic basis of inherited disease. New York: McGraw-Hill, 1983.

6 Rothhammer F, Cruz-Coke R. Curso basico de genetica humana. Santiago, Chile: Editorial Universitaria, 1977.

7 Cifuentes L, Valenzuela CY, Cruz-Coke R, Armanet L, Lyng $C$, Harb $Z$. Caracterizacion genetica de la poblacion hospitalaria de Santiago. Rev Med Chile 1988;116:28-33.

8 Pinto-Cisternas J, Salinas C, Campusano C, Figueroa M Lazo B. Migration in a population of Valparaiso, Chile. Soc Biol 1971;18:431-6.

9 Pinto G, Ilic P, Paredes L, Valenzuela CY. Sistemas sanguineos ABO y Rhesus en personas de estrato socioeconomico medio y alto. Rev Med Chile 1981;109:120911.

10 Cruz-Coke R. Estructura del genomio morbido de la poblacion chilena. Rev Med Chile 1985;113:436-41.

11 Cortes F, Alliende MA, Verdaguer J, Frias D. Estudio de una poblacion aislada con una alta incidencia de acromatopsia.
Estimacion de la consanguinidad y consideraciones clinEstimacion de la consanguinidad y consider

12 Reginato A, Lee J, Martinez V, et al. Condrocalcinosis articular familiar en las islas de Chiloe. Rev Med Chile 1976;104:69-76.

13 Galvez S, Carter L. Analisis clinico de una serie de 69 casos definitivos de enfermedad de Creutzfeldt-Jakob ocurridos en Chile entre 1960 y 1985. Rev Med Chile 1987;115 $1148-54$.

14 Reyes H, Gonzalez MC, Ribalta J, et al. Prevalence of intrahepatic cholestasis of pregnancy in Chile. Ann Intern Med 1978;88:487-93.

15 Goldsmith RI, Rothhammer F, Schull WJ. Mydriasis and heredity. Clin Genet 1977;12:129-33. 
16 Moreno RS, Barton SA, Acuña M. Politelia en el norte de Chile. XXIII Meeting of the Genetics Society of Chile, Valparaiso, Chile, 1990:33A.

17 Moreno RS. Perfil etnomedico de la comunidad de TrapaTrapa. XII National Congress of Chilean Archeology, Temuco, Chile, 1991:61A

18 Nazer J, Diaz G, Pizarro MT. Estudio clinico y epidemiologico de las malformaciones congenitas: incidencia de malformaciones congenitas en el area norte de Santiago. Rev Pediatr (Santiago) 1979;22:70-6.

19 Organizacion Panamericana de la Salud (OPS). Las condiciones de salud en la Americas. Public Cientific No 524 Washington, 1990

20 Medina E, Kaempffer AM. Los hospitales chilenos: dotacion y productividad de los sectores publicos y privado. Rev Med Chile 1992;120:334-41.
21 Valenzuela CY, Acufia M, Harb Z. Gradiente sociogenetico en la poblacion chilena. Rev Med Chile 1987;115:296-9. 22 Cruz-Coke R, Rivera L. Genetic characteristics of hemophilia A in Chile. Hum Hered 1980;30:161-9.

23 Cruz-Coke R. Epidemiologia genetica del corea de Hun tington en Chile. Rev Med Chile 1987;115:483-5.

24 Cornejo V, Raimann E, Perales CG, Colombo M. Diagnostico y seguimiento de los errores congenitos del metabolismo en Chile. Rev Brasil Genet 1992;15(suppl 2):96

25 Holmgren J, Reyes J, Colombo M, Blanco MA. Distrofia muscular de Duchenne y Becker en Chile. Rev Med Chile 1992;120:288-92.

26 Cruz-Coke R, Valenzuela CY. Enfermedades hereditarias en un hospital gener. Rev Med Chil 1973;101:212-15. Nagel R, Soto O. Haptoglobin types in native chilean. A hybrid population. Am $\mathcal{J}$ Phys Anthropol 1964;22:335-41.
hel 